\title{
EFFECT OF LIPID A AND FATTY ACIDS ON TRANS- PORT ACTIVITIES OF MEMBRANE VESICLES FROM ESCHERICHIA COLI
}

\author{
JIUNU-SHYONG LAI, SHIN-ICHI OKUDA, HIROSHI ABE,* \\ and HAJIME TAKAHASHI \\ Department of Agricultural Chemistry, Faculty of Agriculture, \\ Tohoku University, Sendai 980 \\ (Received: September 17, 1975)
}

\begin{abstract}
The effect of lipid A from Salmonella typhimurium and various fatty acids on the transport activities of membrane vesicles from Escherichia coli was investigated. It was found that lipid $\mathrm{A}$ and fatty acids severely inhibited the accumulation of succinate or serine which are coupled to the electron transport, while the transport of glucose, which was catalyzed by the phosphotransferase system, was stimulated slightly by these compounds. Lipid A and myristic acid appeared to act at the same site in the succinate transport system, since no additive effect was observed in the inhibition even at a low concentration of these compounds. Lipid A and myristic acid caused the efflux of pre-loaded ${ }^{14} \mathrm{C}$-succinate in the membrane vesicles.
\end{abstract}

Lipopolysaccharide is a constituent of the outer cell wall of Gram-negative bacteria, and, as endotoxin, it has a wide variety of biological activities toward animals (1). Chemically, lipopolysaccharide is a macromolecule made up of Oantigen, core, and lipid A (2). It has been shown that lipid A moiety plays a dominant role in the endotoxic activities (3-5) and that lipid $\mathrm{A}$ is a glycolipid composed of $\beta$-glucosaminylglucosamine, hydroxyl and amide groups in which are acylated (6-8). Recent observation by Kato (9) has shown that lipid A inhibits respiration and phosphorylation when it is preincubated with mouse liver mitochondrial suspension.

In bacteria, enzyme systems involved in respiration and phosphorylation are membrane bound. Since similarities exist between the structure and function of mitochondria and those of bacterial membranes, it would be interesting to investigate the effect of lipid $A$ on the function of cytoplasmic membranes.

This paper describes the effect of lipopolysaccharide, lipid A, fatty acids, and

* Present address: Meiji Milk Products Co., Ltd., Inazawa, Aichi-ken 492 
other hydrophobic compounds on the transport systems of membrane vesicles. Results obtained showed that lipid A and certain fatty acids inhibit the accumulation of succinate or serine which couples to the electron transport (10-13), while no such effect was observed on the transport of glucose which utilizes phosphoenolpyruvate phosphotransferase system (14).

\section{MATERIALS AND METHODS}

Organisms. Escherichia coli W2252 and Salmonella typhimurium TV119 were used.

Preparation of membrane vesicles. The cells of E. coli W2252 were grown in a nutrient broth medium supplemented with $0.2 \%$ succinate (12) and the membrane vesicles were prepared according to the method described by MURAKAWA et al. (12) which was almost similar to the method of KABACK (14).

Preparation of lipid $A$. The cells of $S$. typhimurium TV119 were grown in the nutrient broth. Lipopolysaccharide was extracted by the method essentially identical to that of OsBORN (15). The crude lipopolysaccharide was partially purified according to the method described by OKUDA et al. (16), except that the Pronase digestion was omitted. The purified lipopolysaccharide was hydrolyzed with $1 \%$ acetic acid to prepare the lipid A fraction (16). Lipid A was dissolved in $\mathrm{Me}_{2} \mathrm{SO}$ at a concentration of $4 \mathrm{mg}$ lipid $\mathrm{A} / 100 \mu \mathrm{l}$.

Analytical methods. Ketodeoxyoctonic acid, as an index compound of lipopolysaccharide, was estimated by the method of WeISSBACH and HURwITz (17) after hydrolysis (18). Sugar was determined by the phenol- $\mathrm{H}_{2} \mathrm{SO}_{4}$ method (19) using glucose as a standard. Fatty acids were estimated according to the method of ITAYA and Ui (20) using myristic acid as a standard. Absorbancy at $260 \mathrm{~nm}$ was measured with a Hitachi 101 spectrophotometer and was expressed as $E_{260}$.

Preparation of phospholipids from E. coli W2252. The cells of E. coli W2252 were grown in the nutrient broth, harvested by centrifugation in the cold, and washed twice with cold $0.01 \mathrm{M}$ Tris- $\mathrm{HCl}$ buffer $(\mathrm{pH} 7.8$ ). The lipid fraction was extracted by the method of BLIGH and DYER (21), and then applied to a silicic acid column. After fatty acids and neutral lipids were eluted with chloroform, the phospholipid fraction was eluted with chloroform-methanol $(1: 1, \mathrm{v} / \mathrm{v})$. This fraction was concentrated in vacuo, and resuspended in $\mathrm{Me}_{2} \mathrm{SO}$ to give $4.4 \mathrm{~mm}$ with respect to phosphate. The suspension was sonicated by an oscillator Model 5202 (Ohtake Works, Tokyo) at $0-4^{\circ}$ for $1 \mathrm{~min}$ at $20 \mathrm{kHz}$.

Uptake studies. The uptake of succinate was measured by the method essentially identical to that of MURAKAwA et al. (12), where $0.2 \mathrm{mg}$ protein of the membrane preparation was diluted to $100 \mu \mathrm{l}$ final volume containing, in final concentrations, $0.05 \mathrm{M}$ potassium phosphate buffer $\left(\mathrm{pH}\right.$ 6.6), $0.01 \mathrm{M} \mathrm{MgSO}_{4}$, and other additions as indicated. The samples in small test tubes were preincubated at $25^{\circ}$ for $15 \mathrm{~min}$. The reaction was started by the addition of ${ }^{14} \mathrm{C}$-succinate 
$(14.4 \mu \mathrm{M}, 0.026 \mu \mathrm{Ci})$ to each sample. D-Lactate ( $5 \mathrm{mM})$, as an energy source, was added just before the addition of ${ }^{14} \mathrm{C}$-succinate. After incubation at $25^{\circ}$ for $3 \mathrm{~min}$, each sample was rapidly diluted with $2 \mathrm{ml}$ of $0.5 \mathrm{M} \mathrm{LiCl}$ held at $25^{\circ}$ to terminate the reaction. Diluted samples were immediately filtered through a Millipore HAWP membrane filter ( $25 \mathrm{~mm}$ diameter) and washed once with $2 \mathrm{ml}$ of $0.5 \mathrm{M} \mathrm{LiCl}$. The dilution, filtration, and washing procedures were performed within $20 \mathrm{sec}$. The filter was immediately removed from a suction apparatus to a glass counting vial. The vials were incubated overnight at $37^{\circ}$ after addition of $1.5 \mathrm{ml}$ of $1.6 \%$ sodium dodecyl sulfate solution. Radioactivity was counted by a Packard Model 3385 Tri-Carb liquid scintillation spectrometer using tolueneNonione scintillation fluid described by KAWAKAMI and SHIMURA (22), except that POPOP was omitted. The uptake of serine was measured similarly to that of succinate, except that the concentration of potassium phosphate buffer was $0.1 \mathrm{M}$, the concentration of D-lactate was $20 \mathrm{mM}$, and ${ }^{14} \mathrm{C}$-serine $(15.6 \mu \mathrm{M}, 0.20 \mu \mathrm{Ci})$ was used instead of ${ }^{14} \mathrm{C}$-succinate. The uptake of glucose was also estimated similarly to that of succinate, except that $0.3 \mathrm{M} \mathrm{LiCl}$ and $0.1 \mathrm{M}$ phosphoenolpyruvate were included in the reaction mixture (14). No addition of D-lactate was made. After preincubation for $15 \mathrm{~min}$ at $25^{\circ},{ }^{14} \mathrm{C}$-glucose $(36.4 \mu \mathrm{M}, 0.09 \mu \mathrm{Ci})$ was added to start the reaction. The incubation time was $25 \mathrm{~min}$.

Other assays. Oxidative activity of the membrane vesicles towards Dlactate was assayed by a conventional Warburg technique at $30^{\circ}$. The reaction mixture contained $4 \mathrm{mg}$ protein of membrane preparation, $50 \mathrm{~mm}$ of D-lactate,

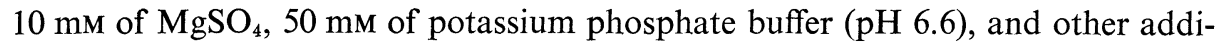
tions as indicated in a total volume of $1.0 \mathrm{ml}$.

$\mathrm{NADH}$ oxidase was assayed at $25^{\circ}$ by following the initial decrease in the absorbance at $340 \mathrm{~nm}$. The assay mixture, in a final volume of $3.3 \mathrm{ml}$, contained $0.05 \mathrm{M}$ of potassium phosphate buffer ( $\mathrm{pH} 6.6$ ), $0.01 \mathrm{M} \mathrm{MgSO}_{4}$, membrane vesicles containing $0.12 \mathrm{mg}$ protein, and other additions as indicated. The samples were incubated at $25^{\circ}$ for $15 \mathrm{~min}$, and then NADH $(0.15 \mathrm{~mm})$ was added to start the reaction. Absorbancy was monitored with a Hitachi Model 124 recording spectrophotometer.

The solubilization of bound ATPase in E. coli W2252 membrane vesicles and the assay of ATPase activity were carried out following the methods described by KobAYASHI and ANRAKU (23), except that bovine serum albumin was omitted from the reaction mixture.

Labeled compounds. Succinic acid $\left[2,3-{ }^{14} \mathrm{C}\right](18 \mathrm{mCi} / \mathrm{mmol})$, L-serine[U- $\left.{ }^{14} \mathrm{C}\right]$ $(130 \mathrm{mCi} / \mathrm{mmol}), \quad$ D-glucose[U- $\left.{ }^{14} \mathrm{C}\right](25.25 \mathrm{mCi} / \mathrm{mmol})$ and myristic acid $\left[1-{ }^{14} \mathrm{C}\right]$ (45 $\mathrm{mCi} / \mathrm{mmol}$ ) were purchased from the Daiichi Pure Chemicals Co., Tokyo.

\section{RESULTS}

\section{Partial purification of lipopolysaccharide}

As shown in Table 1, the lipopolysaccharide preparation purified by DNase 
Table 1. Partial purification of lipopolysaccharide from S. typhimurium.

\begin{tabular}{|c|c|c|c|c|c|c|c|}
\hline \multirow{2}{*}{$\begin{array}{l}\text { Purification } \\
\text { steps }\end{array}$} & KDO & Sugars & Fatty acids & \multirow[t]{2}{*}{$\mathrm{E}_{260}$} & \multirow{2}{*}{$\begin{array}{c}\text { Sugars/ } \\
\text { KDO }\end{array}$} & \multirow{2}{*}{$\begin{array}{l}\text { Fatty } \\
\text { acids/ } \\
\text { KDO }\end{array}$} & \multirow{2}{*}{$\begin{array}{l}\mathrm{E}_{280} / \\
\mathrm{KDO}\end{array}$} \\
\hline & \multicolumn{3}{|c|}{$\mu \mathrm{mol}$} & & & & \\
\hline $45 \%$ phenol extract & 83 & 1,550 & $\begin{array}{c}308 \\
(23.0)\end{array}$ & 7,225 & 18.7 & 3.7 & 87.1 \\
\hline DNase & 80 & 605 & - & 532 & 7.6 & - & 6.7 \\
\hline RNase UC-1 & 79 & 436 & $\begin{array}{c}263 \\
(0.18)\end{array}$ & 264 & 5.5 & 3.3 & 3.3 \\
\hline UC-2 & 73 & 407 & $\begin{array}{c}242 \\
(0.02)\end{array}$ & 264 & 5.6 & 3.3 & 3.6 \\
\hline
\end{tabular}

The purification was performed with $120 \mathrm{~g}$ (wet weight) of bacterial cells.

UC-1 and UC-2 represent the first and the second ultracentrifugations, respectively.

Numbers in parentheses indicate the percentages of fatty acids soluble in chloroformmethanol to the total fatty acids of the preparations.

KDO: ketodeoxyoctonic acid.

Table 2. Effect of lipid A on succinate, serine, and glucose uptakes.

\begin{tabular}{llcccc}
\hline \multirow{2}{*}{ Substrate } & \multicolumn{2}{c}{ Concentration (\%) of } & \multicolumn{3}{c}{ Uptake } \\
\cline { 4 - 6 } & lipid A & $\mathrm{Me}_{2} \mathrm{SO}$ & $\begin{array}{c}\text { (pmol/mg protein/min) } \\
\text { without } \\
\text { lipid A }\end{array}$ & $\begin{array}{c}\text { Inhibition } \\
\text { with } \\
\text { lipid A }\end{array}$ \\
\hline \multirow{3}{*}{ Succinate } & 0 & 0 & 18 & - & - \\
& 0.04 & 1 & 19 & 8 & 55 \\
& 0.08 & 2 & 19 & 3 & 82 \\
Serine & 0.12 & 3 & 20 & 3 & 83 \\
& 0 & 0 & 47 & - & - \\
& 0.04 & 1 & 58 & 26 & 56 \\
Glucose & 0.08 & 2 & 54 & 19 & 64 \\
& 0.12 & 3 & 55 & 11 & 80 \\
& 0 & 0 & 9 & - & - \\
& 0.04 & 1 & 9 & 10 & $-11^{b}$ \\
& 0.08 & 2 & 9 & 11 & $-22^{b}$ \\
& 0.12 & 3 & 10 & 12 & $-20^{b}$ \\
\hline
\end{tabular}

a An equal amount of $\mathrm{Me}_{2} \mathrm{SO}$ as in the system with lipid $\mathrm{A}$ was added to the controls.

$b$ Minus indicates stimulation.

and RNase treatments followed by the first and second ultracentrifugations had the ratios of sugars to ketodeoxyoctonic acid, fatty acids to ketodeoxyoctonic acid, and $\mathrm{E}_{260}$ to ketodeoxyoctonic acid of 5.6, 3.3, and 3.6, respectively. Noteworthy was the fact that the amount of fatty acids in lipids soluble in chloroformmethanol $(1: 1, \mathrm{v} / \mathrm{v})$ which were mostly phospholipids and contaminated in the crude lipopolysaccharide was reduced by the purification from 23.0 to $0.02 \%$ of the total fatty acids. Therefore, the purified lipopolysaccharide was used to prepare the lipid A fraction. 
Effect of lipid A on succinate, serine, and glucose uptakes

As shown in Table 2, about $80 \%$ inhibition of the succinate uptake was observed with lipid A at $0.08 \%$, but no further inhibition occurred even when the concentration of lipid A was increased. The uptake of serine was also severely inhibited by lipid A (Table 2). Lipid A had the same inhibitory effect on succinate and serine uptake when ascorbate $(10 \mathrm{~mm})$ plus phenazine methosulfate $(0.3 \mathrm{~mm})$ or NADH $(10 \mathrm{~mm})$ served as energy sources instead of D-lactate. On the contrary, a slight stimulative effect of lipid A was observed on the glucose uptake catalyzed by the phosphoenolpyruvate phosphotransferase system as shown in Table 2.

Table 3. Effect of fatty acids on succinate uptake.

\begin{tabular}{|c|c|c|}
\hline \multirow{2}{*}{$\begin{array}{c}\text { Fatty acids added } \\
\\
0.88 \mathrm{~mm}\end{array}$} & \multicolumn{2}{|c|}{ Succinate uptake } \\
\hline & $\mathrm{pmol} / \mathrm{mg}$ protein $/ 3 \mathrm{~min}$ & Inhibition $(\%)$ \\
\hline None & 92 & - \\
\hline $\mathrm{C}_{1: 0}$ & 86 & 6 \\
\hline $\mathrm{C}_{2: 0}$ & 85 & 8 \\
\hline $\mathrm{C}_{3: 0}$ & 74 & 20 \\
\hline $\mathrm{C}_{4: 0}$ & 80 & 13 \\
\hline$C_{5: 0}$ & 72 & 22 \\
\hline$C_{6: 0}$ & 44 & 52 \\
\hline $\mathrm{C}_{10: 0}$ & 25 & 73 \\
\hline $\mathrm{C}_{12: 0}$ & 18 & 80 \\
\hline $\mathrm{C}_{13: 0}$ & 18 & 80 \\
\hline $\mathrm{C}_{14: 0}$ & 17 & 81 \\
\hline $\mathrm{C}_{16: 0}$ & 73 & 21 \\
\hline$C_{18: 0}$ & 83 & 10 \\
\hline$C_{18: 1}$ & 17 & 81 \\
\hline$\alpha-\mathrm{OH} \mathrm{C} \mathrm{C}_{14: 0}$ & 66 & 28 \\
\hline$\beta-\mathrm{OH} \mathrm{C} \mathrm{C}_{14: 0}$ & 15 & 84 \\
\hline$\beta-\mathrm{OH} \mathrm{C}_{14: 0}-\mathrm{C}_{14: 0^{b}}$ & 93 & 0 \\
\hline
\end{tabular}

$a$ Each fatty acid was dissolved in $\mathrm{Me}_{2} \mathrm{SO}$ at a concentration of $4.4 \mathrm{~mm}$ and added to the reaction mixture. The control contained the same amount of $\mathrm{Me}_{2} \mathrm{SO}$.

${ }_{b} \quad \beta$-Myristoxymyristic acid was chemically synthesized.

Effect of fatty acids on succinate, serine, and glucose uptakes

Since lauric, myristic, palmitic, $\beta$-hydroxymyristic, and $\beta$-myristoxymyristic acids are known to be the components of lipid A from Salmonella species (24), the effect of these and other fatty acids on the succinate uptake was examined. Table 3 shows that all the fatty acids listed here except $\beta$-myristoxymyristic acid more or less inhibited the uptake. Among non-hydroxy saturated fatty acid series with $\mathrm{C}_{4}$ to $\mathrm{C}_{14}$, the inhibition generally increased with the elongation of chain length. Thus, myristic acid was the most potent inhibitor. Upon further elongation of the carbon chain, however, the inhibitory effect was dramatically reduced. Although stearic acid was a poor inhibitor, oleic acid was one of the 
Table 4. Effect of fatty acids on serine and glucose uptake.

\begin{tabular}{llcc}
\hline \multirow{2}{*}{ Substrate } & Fatty acids added & \multicolumn{2}{c}{ Uptake } \\
\cline { 3 - 4 } & $0.88 \mathrm{~mm}$ & pmol/mg protein $/ \mathrm{min}$ & Inhibition $(\%)$ \\
\hline \multirow{3}{*}{ Serine } & None & 48 & - \\
& $\mathrm{C}_{14: 0}$ & 7 & 85 \\
& $\beta-\mathrm{OH} \mathrm{C} \mathrm{C}_{14: 0}$ & 6 & 87 \\
\hline \multirow{3}{*}{ Glucose } & None & 9 & $-11^{a}$ \\
& $\mathrm{C}_{14: 0}$ & 10 & $-22^{a}$ \\
\hline
\end{tabular}

Experimental conditions were the same as in Table 3.

a Minus indicates stimulation.

Table 5. Effect of succinate on myristate uptake ${ }^{a}$

\begin{tabular}{lcc}
\hline \multicolumn{1}{c}{ Addition } & \multicolumn{2}{c}{ Myristate uptake } \\
\cline { 2 - 3 } & pmol/mg protein/ $3 \mathrm{~min}$ & Inhibition $(\%)$ \\
\hline D-Lactate & 4,026 & 0 \\
Without D-lactate & 4,037 & 0 \\
D-Lactate plus succinate ${ }^{b}$ & 4,059 & \\
\hline$a \quad$ Uptake of myristate was measured similarly to that of succinate, except that ${ }^{14} \mathrm{C}-$ \\
myristic acid $(22 \mu \mathrm{M}, 0.1 \mu \mathrm{Ci})$ was used instead of ${ }^{14} \mathrm{C}$-succinic acid. \\
b Unlabeled sodium succinate $(2,000 \mu \mathrm{M})$ was added just before the addition of \\
${ }^{14} \mathrm{C}$-myristic acid.
\end{tabular}

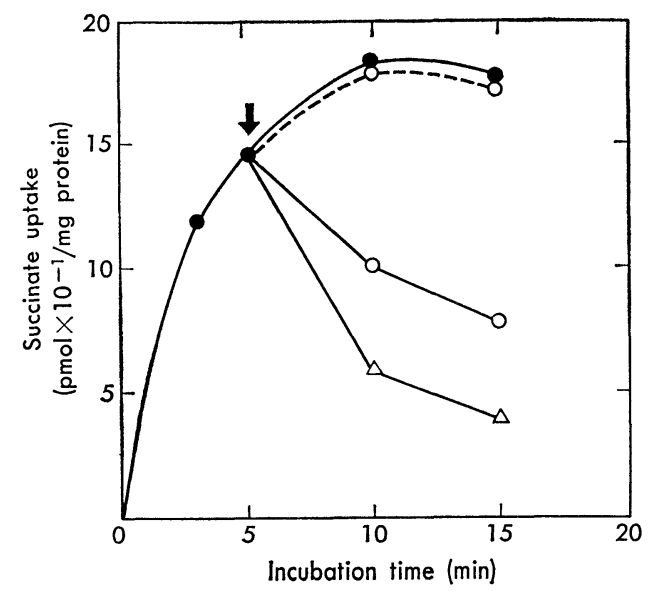

Fig. 1. Efflux of succinate by lipid $A$ and myristic acid.

The time course of succinate uptake was measured by standard conditions (- and lipid $\mathrm{A}\left(0.08 \%\right.$ in $\left.2 \% \mathrm{Me}_{2} \mathrm{SO}\right)(-\mathrm{O}-)$, myristic acid $\left(0.88 \mathrm{~mm}\right.$ in $\left.2 \% \mathrm{Me}_{2} \mathrm{SO}\right)$ $(-\triangle-)$, and $\mathrm{Me}_{2} \mathrm{SO}(2 \%)$ (---O--) were added at the time indicated by the arrow. 
most powerful inhibitors. Among hydroxy acids, inhibition by $\beta$-hydroxymyristic acid was about $80 \%$, while that of $\alpha$-hydroxymyristic acid was only $28 \%$. $\beta$ Myristoxymyristic acid had no inhibitory effect. As shown in Table 4, the serine uptake was also susceptible to fatty acids. Approximately $90 \%$ inhibition was observed with myristic and $\beta$-hydroxymyristic acids. However, these fatty acids slightly stimulated the glucose transport (Table 4).

\section{Effect of succinate on fatty acid uptake}

Since carboxyl group is present in fatty acid as in succinic acid and serine, it is possible that fatty acid may serve as an analog to the transport system of succinate or serine. To examine this possibility, the effect of succinate on the uptake of fatty acid was examined. As shown in Table 5, a large amount of ${ }^{14} \mathrm{C}$-myristic acid was taken up or bound by membranes independently of the energy source provided. Succinate at 100 times higher concentration than that of ${ }^{14} \mathrm{C}$-myristic acid did not inhibit the uptake of myristic acid. These results suggested that fatty acid did not serve as an analog of succinate.

\section{Effect of lipid $A$ and myristic acid on the efflux of pre-loaded succinate}

As shown above, lipid A and certain fatty acids inhibited the uptake systems coupled to the electron transport. Glucose uptake catalyzed by the phosphotransferase system, on the other hand, was stimulated by lipid A and fatty acids. These results may indicate that lipid A and fatty acids inhibit the electron transport and/or energy coupling to the transport system. If this is the case, the efflux of

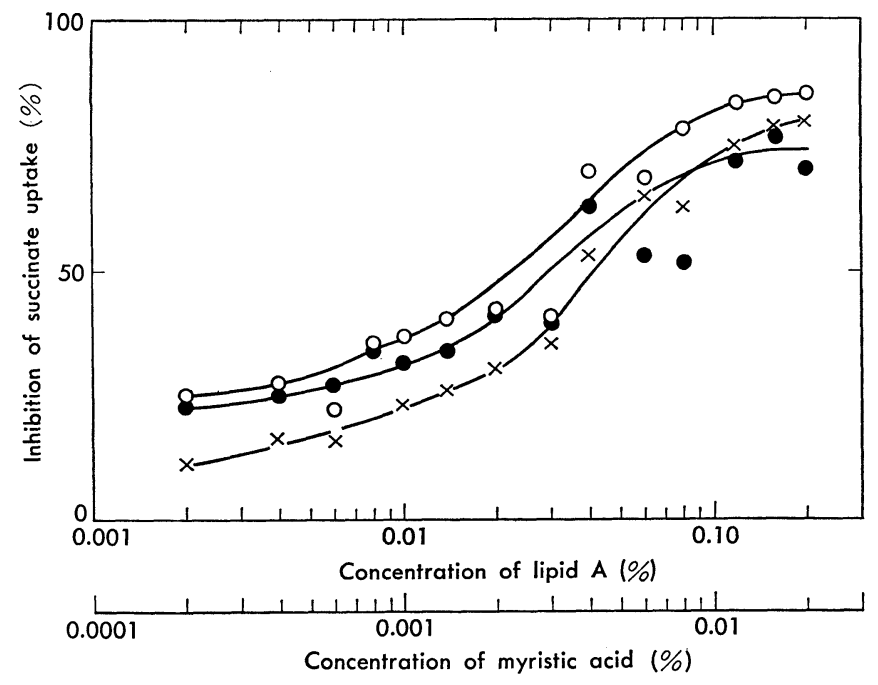

Fig. 2. Effect of lipid $\mathrm{A}$ and myristic acid on succinate uptake.

Lipid A (- - ) , myristic acid (- --$)$, and both lipid A and myristic acid (-O-) were added to each sample at the concentrations indicated. 
pre-loaded ${ }^{14} \mathrm{C}$-succinate should occur by the addition of lipid A or fatty acids. As shown in Fig. 1, the efflux of more than $50 \%$ of ${ }^{14} \mathrm{C}$-succinate, pre-loaded in the membrane vesicles, was observed within 10 min after the addition of lipid A or myristic acid.

\section{Effect of simultaneous addition of lipid $A$ and myristic acid on succinate uptake}

As shown in Fig. 2, no additive effect in the inhibition of the succinate uptake was observed by the simultaneous addition of lipid A and myristic acid, over the concentration ranges examined. Although the data are not conclusive, it appears that lipid A and myristic acid inhibit the succinate transport system at the same site.

\section{Effect of lipid $A$ and myristic acid on D-lactate and NADH oxidation}

As shown in Table 6, lipid A slightly inhibited the D-lactate oxidation by the membrane vesicles. Myristic acid, however, slightly stimulated the D-lactate oxidation. The addition of lipid A or myristic acid slightly inhibited the NADH oxidase activity (Table 6). Therefore, it seems unlikely that the inhibition of transport systems by these compounds is due to the block of respiration.

Table 6. Effect of lipid A and myristic acid on D-lactate and NADH oxidation activity.

\begin{tabular}{|c|c|c|c|c|c|}
\hline \multirow[t]{2}{*}{ Additions } & \multirow{2}{*}{$\begin{array}{c}\text { Concentra- } \\
\text { tion }\end{array}$} & \multicolumn{2}{|c|}{ D-Lactate oxidation } & \multicolumn{2}{|c|}{ NADH oxidation } \\
\hline & & $\left(\mathrm{Q}_{2}\right)$ & $\begin{array}{c}\text { Inhibition } \\
(\%)\end{array}$ & $\begin{array}{l}\text { (decrease in } \\
\text { absorbance at } \\
340 \mathrm{~nm} / \mathrm{min} \text { ) }\end{array}$ & $\begin{array}{c}\text { Inhibition } \\
(\%)\end{array}$ \\
\hline None & - & 23.1 & - & 0.28 & - \\
\hline $\mathrm{Me}_{2} \mathrm{SO}$ & $2 \%$ & 23.2 & 0 & 0.28 & 0 \\
\hline Lipid A & & & & & \\
\hline in $\mathrm{Me}_{2} \mathrm{SO}(2 \%)$ & $0.08 \%$ & 20.5 & 12 & 0.26 & 7 \\
\hline Myristic acid & & & & & \\
\hline in $\mathrm{Me}_{2} \mathrm{SO}(2 \%)$ & $0.88 \mathrm{mM}$ & 28.5 & $-23^{a}$ & 0.23 & 18 \\
\hline
\end{tabular}

a Minus indicates stimulation.

Table 7. Effect of lipid A and myristic acid on ATPase activity.

\begin{tabular}{|c|c|c|c|c|c|}
\hline \multirow[t]{2}{*}{ Addition } & \multirow{2}{*}{$\begin{array}{c}\text { Concentra- } \\
\text { tion }\end{array}$} & \multicolumn{2}{|c|}{$\begin{array}{l}\text { Membrane-bound } \\
\text { ATPase activity }\end{array}$} & \multicolumn{2}{|c|}{$\begin{array}{c}\text { Solubilized } \\
\text { ATPase activity }\end{array}$} \\
\hline & & $\begin{array}{c}\mu \mathrm{mol} / \mathrm{mg} \\
\text { protein } / \mathrm{min}\end{array}$ & $\underset{(\%)}{\text { stimulation }}$ & $\begin{array}{l}\mu \mathrm{mol} / \mathrm{mg} \\
\text { protein } / \mathrm{min}\end{array}$ & $\begin{array}{c}\text { Inhibition } \\
(\%)\end{array}$ \\
\hline None & - & 0.029 & - & 21.2 & - \\
\hline $\mathrm{Me}_{2} \mathrm{SO}$ & $2 \%$ & 0.029 & 0 & 21.2 & 0 \\
\hline $\begin{array}{l}\text { Lipid } \mathrm{A} \\
\text { in } \mathrm{Me}_{2} \mathrm{SO}(2 \%) \\
\text { Myristic acid }\end{array}$ & $0.08 \%$ & 0.029 & 0 & 20.2 & 5 \\
\hline in $\mathrm{Me}_{2} \mathrm{SO}(2 \%)$ & $0.88 \mathrm{~mm}$ & 0.068 & 135 & 15.3 & 28 \\
\hline
\end{tabular}




\section{Effect of lipid $A$ and myristic acid on ATPase activity}

It is known that $\mathrm{Ca}^{2+}-\mathrm{Mg}^{2+}$-stimulated ATPase is a coupling factor of bacterial oxidative phosphorylation (25). As shown above, there are some indirect evidences that lipid A and fatty acids may interfere in the oxidative energy generation. Therefore, the effect of lipid $\mathrm{A}$ and myristic acid on $\mathrm{Ca}^{2+}-\mathrm{Mg}^{2+}$-stimulated ATPase activities, membrane-bound and solubilized forms, were investigated. As shown in Table 7, myristic acid remarkably stimulated the membrane-bound ATPase activity, but slightly inhibited the solubilized ATPase. On the other hand, lipid A did not affect significantly the membrane-bound and solubilized ATPase activities.

Effect of various hydrophobic substances on succinate uptake

Effect of various compounds on the succinate uptake is summarized in Table 8. Although lipid A is a potent inhibitor, lipopolysaccharide inhibited only slightly. Compounds with modified carboxyl group, methyl laurate and lauryl alcohol, were moderate inhibitors. A more remarkable inhibition was observed with phospholipids, soybean lecithin and $E$. coli phospholipids. Triglyceride and $\mathrm{N}$-acetylmethionine had no effect. Hexane $(0.88 \mathrm{~mm}$, i.e., $0.007 \%)$ inhibited the

Table 8. Effect of various substances on succinate uptake.

\begin{tabular}{|c|c|c|c|}
\hline \multirow[b]{2}{*}{ Additions $^{a}$} & \multirow{2}{*}{$\begin{array}{l}\text { Concentration } \\
\text { (mM) }\end{array}$} & \multicolumn{2}{|c|}{ Succinate uptake } \\
\hline & & $\begin{array}{c}\mathrm{pmol} / \mathrm{mg} \\
\text { protein } / 3 \mathrm{~min}\end{array}$ & $\begin{array}{c}\text { Inhibition } \\
(\%)\end{array}$ \\
\hline None & - & 141 & - \\
\hline \multirow[t]{2}{*}{ Lipopolysaccharide $^{b}$} & 0.88 & 145 & $-3^{c}$ \\
\hline & 2.80 & 128 & 9 \\
\hline \multirow[t]{2}{*}{ Methyl laurate } & 0.88 & 64 & 55 \\
\hline & 1.76 & 64 & 55 \\
\hline Lauryl alcohol & 0.88 & 56 & 60 \\
\hline \multirow[t]{2}{*}{ Soybean lecithin } & 0.88 & 59 & 58 \\
\hline & 1.76 & 34 & 76 \\
\hline \multirow[t]{2}{*}{ E. coli phospholipid } & 0.88 & 44 & 69 \\
\hline & 1.76 & 30 & 79 \\
\hline \multirow[t]{2}{*}{ Triglyceride $^{d}$} & 0.44 & 151 & $-7^{c}$ \\
\hline & 0.88 & 141 & 0 \\
\hline \multirow[t]{2}{*}{$\mathrm{N}$-acetylmethionine } & 0.88 & 135 & 4 \\
\hline & 1.76 & 141 & 0 \\
\hline Hexane & 0.88 & 113 & 20 \\
\hline Ligroin (boiling range $75-120^{\circ}$ ) & $0.007 \%$ & 141 & 0 \\
\hline
\end{tabular}

a Each compound, except lipopolysaccharide, was dissolved in $\mathrm{Me}_{2} \mathrm{SO}(2 \%)$ and added to the reaction mixture.

$b$ Lipopolysaccharide was suspended in water and was added as such. The molar concentration was expressed on the basis of the amount of fatty acids in the preparation.

c Minus indicates stimulation.

$d$ Acyl groups were the mixtures of $\mathrm{C}_{6: 0}, \mathrm{C}_{8 \cdot 0}, \mathrm{C}_{10: 0}$, and $\mathrm{C}_{12: 0}$. 
uptake by about $20 \%$ while no inhibition was observed with ligroin $(0.007 \%)$. Whether or not the compounds listed in Table 8 inhibited the uptake at the same site as lipid A or fatty acids is unknown.

\section{DISCUSSION}

It is of interest to ask just how lipid A and fatty acids inhibited active transport of succinate or serine which is coupled to the electron transport. Since both these systems were inhibited, it is likely that lipid A and fatty acids act at a site common to the two systems. Therefore, it is unlikely that the specific membrane carriers per se are affected directly by lipid A and fatty acids. Since the mechanisms of energy generation and of coupling this energy to the active transport are common to many systems (25), energy generation and/or energy coupling might be the potential target of lipid A and fatty acids. The following evidences support this hypothesis. First, lipid A and certain fatty acids inhibited succinate and serine accumulation driven by the oxidation of D-lactate, while they stimulated slightly the glucose transport catalyzed by phosphoenolpyruvate phosphotransferase system. Second, both lipid A and myristic acid caused the efflux of preloaded ${ }^{14} \mathrm{C}$-succinate of the membrane vesicles. Finally, myristic acid stimulated the membrane-bound ATPase activity, indicating that the compound affected membrane vesicles in a certain manner. Although we cannot determine at the present time whether lipid A and fatty acids act directly on oxidative phosphorylation or they interfere in the energy coupling to the transport system, the site of action of these compounds appears to be the oxidative phosphorylation in view of the reported inhibition of oxidative phosphorylation in mitochondria by lipid A (9) and by endogenous fatty acids $(26,27)$.

Apart from the uncoupling of oxidative phosphorylation, it can also be considered that lipid A and fatty acids solubilized proteins and/or phospholipids of the membrane vesicles to form "holes," and thus, the membranes no longer have the capacity of retaining succinate or serine. This possibility is probably excluded because glucose transport occurred even in the presence of lipid A or fatty acids. It should be mentioned, however, that glucose phosphate is the primary compound which accumulates in the membranes, a characteristic property of the phosphotransferase system. Therefore, if we consider that the "holes" do not permit the efflux of phosphorylated compounds, this possibility could not entirely be excluded.

Another possibility of the inhibition by lipid A and fatty acids may be the attachment of these compounds to the binding proteins involved in the transport of succinate or serine. If this is the case, the binding of fatty acids should be inhibited by succinate or serine. However, the binding of myristic acid to the membranes was not inhibited by a very high concentration of succinate. Thus, the possibility of attachment of fatty acid to binding proteins may be excluded.

Although D-lactate as well as $\mathrm{NADH}$ served as an electron donor for the ac- 
cumulation of succinate or serine in our membrane preparations, it is generally believed that ATP and NADH are essentially impermeable to bacterial membranes (28). It is suggested that the NADH oxidase activity is associated with the inverted (inside out) membrane vesicles (28). If this is the case, the stimulation of $\mathrm{Ca}^{2+}-\mathrm{Mg}^{2+}$-ATPase activity of the membrane vesicles by myristic acid might be explained by an increased inversion of the vesicles, which may result in the stimulation of NADH oxidase activity. The present data showed, however, that myristic acid slightly inhibited the NADH oxidase activity.

It is of interest to note that the inhibitory effect of saturated fatty acids increased with the elongation of carbon chain up to $\mathrm{C}_{14}$. The inhibition by palmitic or stearic acids was much less compared to that by myristic acid. It is not known whether or not the weak inhibitory effect is due to the solubility of these compounds. It should be pointed out, however, that, beside solubility, the chemical structure of a given fatty acid is important for it to act as the inhibitor, because $\beta$-hydroxymyristic acid was a potent inhibitor but $\alpha$-hydroxymyristic acid was a poor inhibitor.

We are grateful to the late Prof. T. Watanabe of the School of Medicine, Keio University, for his generous supply of Salmonella typhimurium TV119 used in this experiment. We are particularly grateful to Dr. S.Murakawa of the Faculty of Agriculture, Tokyo Noko University, for his generous help at the initiation of this study. We also thank Miss K. Saito of this Faculty for her help in the radioassays.

\section{REFERENCES}

1) R. P. Gibert, Physiol. Rev., 40, 245 (1960).

2) O. Lüderitz, O. Westphal, A. M. Staub, and H. Nikaido, In Microbial Toxins, ed. by G. Weinbaum, S. Kadis, and S. J. AJl, Academic Press, Inc., New York, Vol. 4, p. 145 (1971).

3) O. Lüderitz, C. Galanos, H. J. Risse, E. Ruschmann, S. Schlecht, G. Schmidt, H. Schulte-Holthausen, R. Wheat, O. Westphal, and J. Schlosshardt, Ann. N.Y. Acad. Sci., 133, 349 (1966).

4) Y. B. KIM and D. W. WAtson, J. Bacteriol., 94, 1320 (1967).

5) C. Galanos, E. T. Rietschel, O. Lüderitz, O. Westphal, Y. B. Kim, and D. W. Watson, Eur. J. Biochem., 31, 230 (1972).

6) J. Gmeiner, O. Lüderitz, and O. WestPhal, Eur. J. Biochem., 7, 370 (1969).

7) Y. Kamio, K. C. Kim, and H. Takahashi, Agr. Biol. Chem. (Tokyo), 36, 2195 (1972).

8) Y. Kamio, K. C. Kim, and H. Takahashi, Agr. Biol. Chem. (Tokyo), 36, 2425 (1972).

9) M. KATO, J. Bacteriol., 112, 268 (1972).

10) S. Murakawa, K. Izaki, and H. Takahashi, Agr. Biol. Chem. (Tokyo), 35, 1992 (1971).

11) M. K. Rayman, T. C. Y. Lo, and B. D. Sanwal, J. Biol. Chem., 247, 6332 (1972).

12) S. Murakawa, K. Izaki, and H. Takahashi, Agr. Biol. Chem. (Tokyo), 37, 1905 (1973).

13) H. R. Kaback and L. S. Milner, Proc. Natl. Acad. Sci. U.S.A., 66, 1008 (1970).

14) H. R. KabaCK, J. Biol. Chem., 243, 3711 (1968).

15) M. J. OsBorn, Methods Enzymol., 8, 161 (1966).

16) S. Okuda, M. Sato, H. Uchiyama, and H. Takahashi, J. Gen. Appl. Microbiol., 21, 167 (1975). 
17) A. Weissbach and J. Hurwitz, J. Biol. Chem., 234, 705 (1959).

18) M. J. Osborn, Proc. Natl. Acad. Sci. U.S.A., 50, 499 (1963).

19) M. Dubois, K. A. Gilles, J. K. Hamilton, P. A. Rebers, and F. Smith, Anal. Chem., 28, 350 (1956).

20) K. Itaya and M. Ui, J. Lipid Res., 6, 16 (1965).

21) E. G. Bligh and W. J. Dyer, Can. J. Biochem. Physiol., 37, 911 (1959).

22) M. KaWAKami and K. Shimura, Radioisotopes, 23, 15 (1974), in Japanese.

23) H. Kobayashi and Y. Anraku, J. Biochem., 71, 387 (1972).

24) E. T. Rietschel, H. Gottert, O. Lüderitz, and O. WestPhal, Eur. J. Biochem., 28, 166 (1972).

25) G. B. Cox and F. Gibson, Biochim. Biophys. Acta, 346, 1 (1974).

26) K. J. Hittelman, O. Lindberg, and B. Cannon, Eur. J. Biochem., 11, 183 (1969).

27) A. Bulychev, R. Kramar, Z. Drahota, and O. Lindberg, Exp. Cell Res., 72,169 (1972).

28) J. F. Hare, K. Olden, and E. P. Kennedy, Proc. Natl. Acad. Sci. U.S.A., 71, 4843 (1974). 